University of Nebraska - Lincoln

DigitalCommons@University of Nebraska - Lincoln

Faculty Publications from the Harold W. Manter Laboratory of Parasitology

8-2003

Tinamutrema canoae n. gen. et n. sp. (Trematoda: Digenea:

Strigeiformes: Brachylaimidae) in Crypturellus cinnamomeus

(Aves: Passeriformes: Tinamidae) from the Área de Conservación Guanacaste, Costa Rica

\author{
David Zamparo \\ University of Toronto \\ Daniel R. Brooks \\ University of Toronto,dnlbrooks@gmail.com \\ Douglas Causey \\ University of Alaska Anchorage, dcausey@uaa.alaska.edu
}

Follow this and additional works at: https://digitalcommons.unl.edu/parasitologyfacpubs

Part of the Parasitology Commons

Zamparo, David; Brooks, Daniel R.; and Causey, Douglas, "Tinamutrema canoae n. gen. et n. sp. (Trematoda: Digenea: Strigeiformes: Brachylaimidae) in Crypturellus cinnamomeus (Aves: Passeriformes: Tinamidae) from the Área de Conservación Guanacaste, Costa Rica" (2003). Faculty Publications from the Harold W. Manter Laboratory of Parasitology. 236.

https://digitalcommons.unl.edu/parasitologyfacpubs/236

This Article is brought to you for free and open access by the Parasitology, Harold W. Manter Laboratory of at DigitalCommons@University of Nebraska - Lincoln. It has been accepted for inclusion in Faculty Publications from the Harold W. Manter Laboratory of Parasitology by an authorized administrator of DigitalCommons@University of Nebraska - Lincoln. 


\title{
TINAMUTREMA CANOAE N. GEN. ET N. SP. (TREMATODA: DIGENEA: STRIGEIFORMES: BRACHYLAIMIDAE) IN CRYPTURELLUS CINNAMOMEUS (AVES, PASSERIFORMES, TINAMIDAE) FROM THE AREA DE CONSERVACIÓN GUANACASTE, COSTA RICA
}

\author{
David Zamparo, Daniel R. Brooks, and Douglas Causey* \\ Department of Zoology, University of Toronto, Toronto, Ontario M5S 3G5, Canada. e-mail: zamparo@zoo.utoronto.ca
}

\begin{abstract}
We propose Tinamutrema as a new genus for Brachylaima centrodes (Braun, 1901) Dollfus, 1935 and for T. canoae, as a new species inhabiting tinamus in the Area de Conservación Guanacaste, Costa Rica. Specimens from Costa Rica resemble $B$. centrodes in having an elongate body, pretesticular genital pore and terminal genitalia, intercecal uterine loops occupying all available space between the anterior testis and the intestinal bifurcation, an oral sucker width:pharynx width ratio of approximately $1: 0.55$, an oral sucker:ventral sucker width ratio of approximately $1: 1$, and vitelline follicles extending into the forebody closer to the pharynx than to the anterior margin of the ventral sucker and by living in the cloaca. They differ from $B$. centrodes in having vitelline follicles that do not extend as far anteriorly as those in $B$. centrodes, which extend anteriorly to the level of the anteriormost extent of the cecal "shoulders," dense tegumental spination as opposed to sparse or no spination, relatively smaller cirrus with fewer spines, longer and more sinous pars prostatica, and forebody averaging $36 \%$ of total body length (TBL) as opposed to $42 \%$ TBL. Both species differ from other members of the Brachylaimidae in possessing a spinose cirrus and a cirrus sac containing both the cirrus and the pars prostatica. Preliminary phylogenetic assessment suggests that these traits are plesiomorphic, and thus the species are basal to the rest of the Brachylaimidae, whose diagnosis we emend accordingly.
\end{abstract}

Brachylaimid digeneans inhabit a variety of mammalian and avian hosts. Species for which life cycles are known develop in both aquatic and terrestrial gastropod or lamellibranch mollusks. Cercariae develop in branched sporocysts, and cercariae either remain in the sporocyst (Krull, 1935) or infect other mollusks of the same or different species (Joyeux et al., 1932; Krull, 1934, 1935; Reynolds, 1938; Alicata, 1940; Pavlov, 1946; Ulmer, 1951a, 1951b; Timon-David, 1959; Jensen, 1972). The definitive host, therefore, must consume mollusks for the life cycle to be completed. Adult worms are parasitic in the large intestine, cloaca, or bursa Fabricius of birds and mammals (Yamaguti, 1971). In this report of the activities of the inventory of eukaryotic parasites of vertebrates in the Area de Conservación Guanacaste in northwestern Costa Rica (for details, see http://brooksweb.zoo.utoronto.ca/index.html), we describe a new species of brachylaimid digenean inhabiting a species of tinamu, and we propose a new genus for it and a similar species inhabiting tinamus in Brazil.

\section{MATERIALS AND METHODS}

Refer to Zamparo et al. (2003a).

\section{DESCRIPTION}

\section{Tinamutrema $\mathrm{n}$. gen.}

Diagnosis: Digenea: Strigeiformes: Brachylaimoidea: Brachylaimidae. Body elongate. Tegument spinose. Oral sucker subterminal. Pharynx present. Prepharynx and esophagus absent. Intestine bifurcating immediately posterior to pharynx, extending anteriad, forming shoulders that extend to level of anterior margin of pharynx. Ceca extending near posterior end of body. Ventral sucker in anterior half of body. Testes at posterior end of body, in tandem. Cirrus sac containing long-spined cirrus and pars prostatica; seminal vesicle external to cirrus sac, internal seminal vesicle absent. Genital pore ventral, medial, intercecal, pretesticular, surrounded by gland cells free in parenchyma. Ovary intertesticular. Ovary spherical to subspherical, 190-247 (223) long by 190220 (209) wide. Ootype anteroventral to ovary, ventral to anterior testis.

Received 9 October 2002; revised 5 March 2003; accepted 5 March 2003.

* Museum of Comparative Zoology, Harvard University, Cambridge, Massachusetts.

Mehlis gland prominent, Laurer canal not observed. Uterus intercecal, in tight transverse coils extending anteriad from ootype region to level of pharynx, descending to genital pore. Metraterm prominent, muscular, straight; external surface densely covered with small gland cells. Vitelline follicles in 2 lateral extracecal fields. Vitelline ducts passing ventral to ceca. Excretory pore dorsal, subterminal. Excretory vesicle bifurcating immediately posterior to ceca. Parasites of the cloaca of birds. Central and South America.

Type species: Tinamutrema canoae $\mathrm{n} . \mathrm{sp}$

\section{Tinamutrema canoae n. sp.}

$$
\text { (Figs. 1-2) }
$$

Description (based on 10 mature specimens): Body elongate, 2.9$3.7 \mathrm{~mm}(3.4 \mathrm{~mm})$ long by 599-697 (646) wide, maximum width in mid-forebody. Tegument spined around anterior end. Oral sucker subterminal, 422-481 (444) long by 355-422 wide (377). Pharynx 209247 (228) long by 190-220 (205) wide. Ratio of oral sucker width to pharyngeal width 1:0.5-0.6 (1:0.55). Prepharynx and esophagus absent. Intestine bifurcating immediately posterior to pharynx, extending anteriad, forming shoulders that extend to level of anterior margin of pharynx. Ceca 95-98\% (97\%) of total body length (TBL). Forebody $31-38 \%(36 \%)$ of TBL. Ventral sucker 348-451 (400) long by 370451 (400) wide. Ratio of oral sucker width to ventral sucker width is $1: 1.0-1.14(1: 1.1)$. Testes $72-79 \%(76 \%)$ of TBL from anterior end of body, in tandem; anterior testis 228-380 (276) long by 247-380 (279) wide. Posterior testis 312-437 (352) long by 217-380 (256) wide, tapering toward posterior end of body. Cirrus sac 228-380 (288) long by 140-228 (180) wide, containing long-spined cirrus, pars prostatica; seminal vesicle external to cirrus sac. Cirrus spines 15-22.0 long, slightly curved and wider by $4-6$ at base. Genital pore ventral, medial, surrounded by gland cells free in parenchyma, $78-79 \%$ of TBL from anterior end of body. Ovary spherical to subspherical, between 2 testes situated in tandem. Ovary 190-247 (223) long by 190-220 (209) wide. Ootype anteroventral to ovary, ventral to anterior testis. Mehlis gland prominent, Laurer canal not observed. Uterus intercecal, in tight transverse coils extending anteriad from ootype region to level of pharynx, descending to genital pore. Metraterm prominent, muscular, folded, 228-304 (262) long by 114-171 (145) wide. Eggs 18-24 (21) long by 11-13 (12.0) wide. Vitelline follicles in 2 lateral extracecal fields, extending anteriorly to intestinal bifurcation, posteriorly to midovarian level; follicles $37.5-47.5$ long by $22.5-32.5$ wide. Total extent of fields $67 \%$ of TBL, anterior extent $15-21 \%(17 \%)$ of TBL from the anterior end of the worm to $14-19 \%(16 \%)$ of TBL from posterior end. Excretory pore dorsal, subterminal. Excretory vesicle Y-shaped, bifurcating immediately posterior to ceca.

\footnotetext{
Taxonomic summary idae).

Type host: Crypturellus cinnamomeus (Aves: Passeriformes: Tinam-
} 


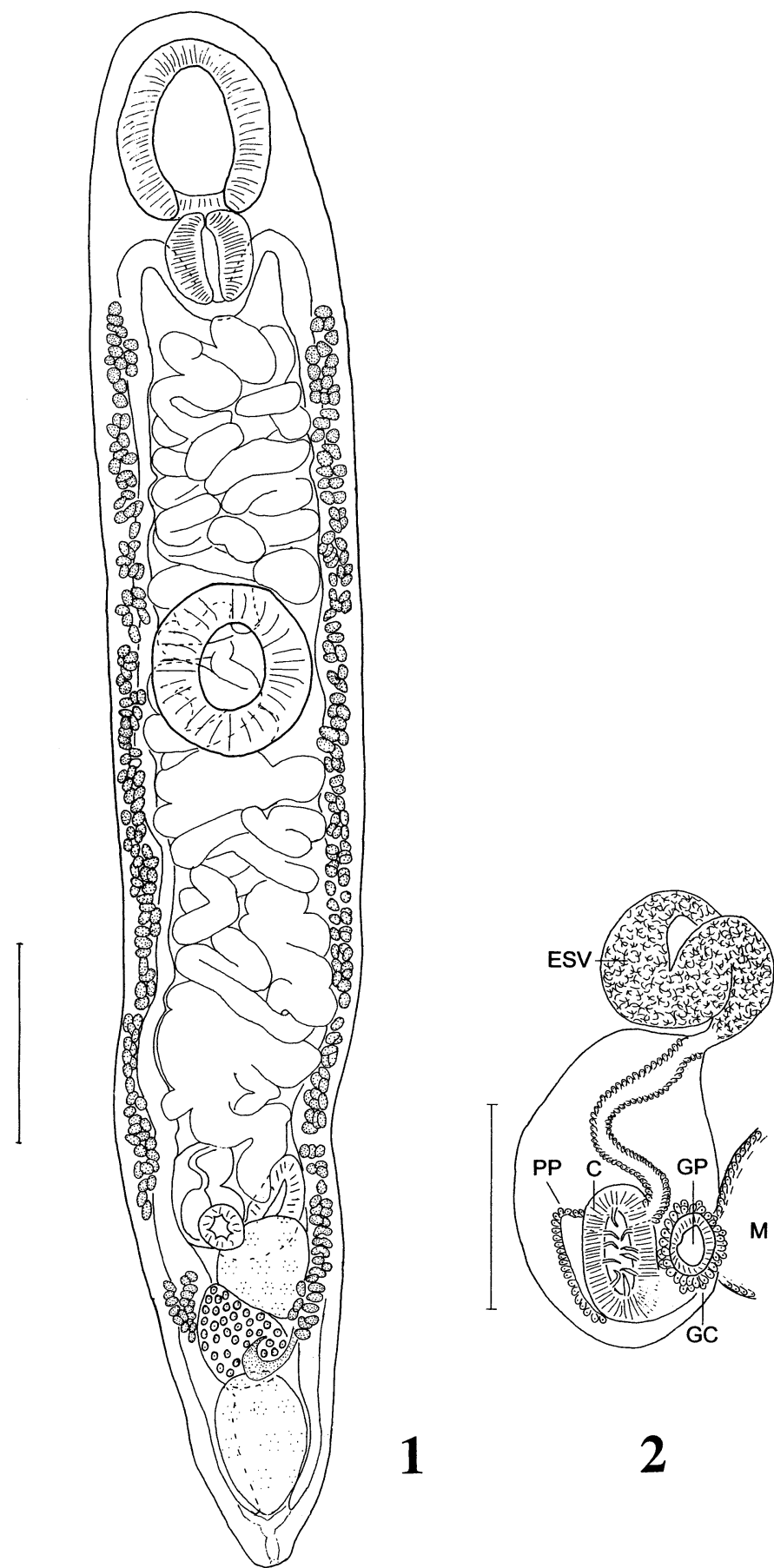

FiguRES 1-2. Tinamutrema canoae n. sp. 1. Ventral view of holotype. Bar $=500 \mu \mathrm{m}$. 2. Terminal genitalia. $\mathrm{C}$, cirrus; ESV, terminal portion of the external seminal vesicle (additional coiling obscured by eggs in uterus); GC, gland cells; GP, genital pore; M, metraterm; PP, pars prostatica. $\mathrm{Bar}=250 \mu \mathrm{m}$.

Prevalence, intensity, site of infection: 1 of 1, 10 worms, cloaca, respectively.

Type locality: Finca Jenny, Sector Santa Rosa (316-134 LN, 364-103 LE, 205 m elevation) $* *=$ Lambert coordinates.

Type material: Holotype, USNPC no. 93190; paratypes, USNPC no. 93191.

Etymology: The new genus is named after the common name of the

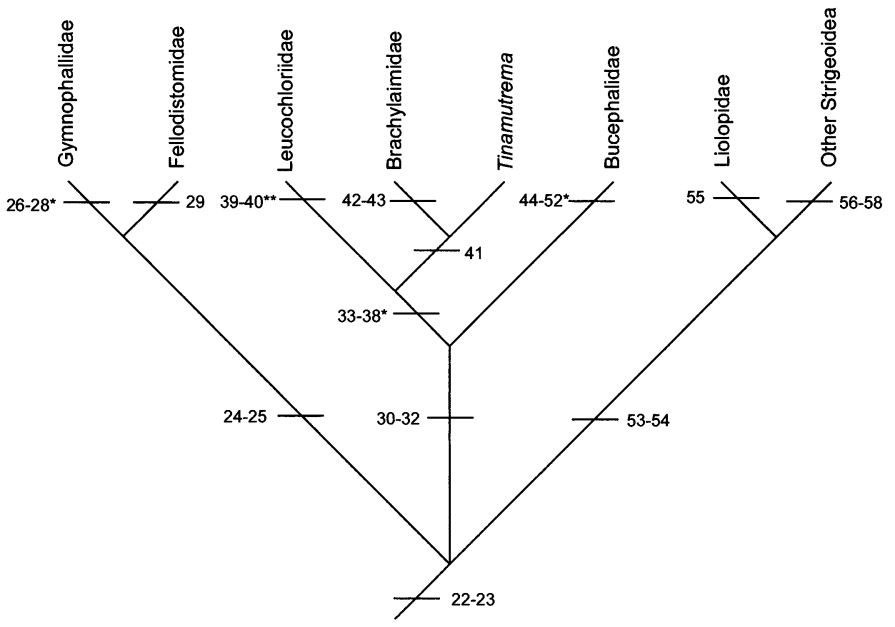

FIGURE 3. Cladogram depicting putative relationships among selected brachylaemoids and their close relatives, based on characters discussed in the text and presented by Brooks et al. $(1985,1989)(*=$ putative homoplasious traits): longifurcate cercariae (22); spinose cirrus in adults (23); setiferous cercarial tail (24); large excretory vesicle in cercariae (vesicle extends into caudal region) (25); no cirrus sac $*(26)$; dichotoma or cercariaeum cercariae (27); germinal sacs reported in some descriptions (28); aspinose tegument (29); subterminal genital pore (30); branched rediae ("branched sporocysts") (31); miracidia with ciliated bars (32); cercariaeum or obscuromicrocercous cercariae (33); stenostomate excretory system (34); testes in adults tandem or oblique at posterior end of the body (35); cecal shoulders present *(36); metraterm with small gland cells lining exterior (37); large gland cells free in parenchyma surrounding male and female terminal genitalia (38); genital pores terminal (39); cirrus aspinose *(40); genital sac containing only pars prostatica and cirrus (41); genital sac containing only cirrus (42); cirrus aspinose *(43); relatively compact preovarian vitellaria (44); acetabulum at anterior end of cercarial body (45); acetabulum at anterior end of adult body (46); mouth midventral in cercariae (47); mouth midventral in adults (48); cercarial intestine saccate (49); adult intestine saccate (50); genital pore terminal (51); longifurcate cercariae with short tail stem (gasterostome type cercariae) (52); paranephridial plexus in cercariae (53); paranephridial plexus in adults (54); lateral genital pores (55); no cirrus *(56); nonpapillose tribocytic organ (57); terminal genital pore (58). Numbers refer to the online database at http:// brooksweb.zoo.utoronto.ca/index.html.

host group, tinamus. The species is named after Sra. Carolina Cano, Area de Conservación Guanacaste (ACG) parataxonomist, in recognition of her outstanding efforts with the parasite inventory.

\section{Remarks}

The specimens described herein closely resemble Brachylaima centrodes (Braun, 1901) Dollfus, 1935, which has been reported in tinamus, as well as other avian hosts from Brazil. We examined 7 specimens of $B$. centrodes from the collection of the Instituto Oswaldo Cruz (nos. $15321,29880,29868$, and 29879) and found that the Costa Rican specimens are very similar to $B$. centrodes in having an elongate body, pretesticular genital pores and terminal genitalia, intercecal uterine loops occupying all available space between the anterior testis and the intestinal bifurcation, an oral sucker width:pharynx width ratio of approximately 1:0.55, an oral sucker:ventral sucker width ratio of approximately $1: 1$, and vitelline follicles extending into the forebody closer to the pharynx than to the anterior margin of the ventral sucker and by living in the cloaca. The specimens from Costa Rica consistently differ from those of $B$. centrodes in having vitelline follicles that do not extend as far anteriorly as those in $B$. centrodes, which extend anteriorly to the level of the anteriormost extent of the cecal "shoulders," a condition never reached in B. canoae, dense tegumental spination as opposed to sparse or no spination, relatively smaller cirrus with fewer spines, longer 
and more sinous pars prostatica, and forebody averaging $36 \%$ of TBL as opposed to $42 \%$ TBL. Consequently, we believe that they represent a species distinct from but closely related to $B$. centrodes.

Braun (1901) placed B. centrodes within Harmostomum, a liolopid, primarily because its members possess a spinose cirrus. Dollfus (1935), however, transferred the species to Brachylaima. Specimens from both Brazil and Costa Rica differ from Harmostomum spp. in lacking the paranephridial plexus that is now considered a synapomorphy linking the Liolopidae with the strigeoid digeneans (Brooks and Overstreet, 1978; Brooks et al., 1985, 1989; Brooks and McLennan, 1993). In addition, they exhibit the very muscular suckers, cecal shoulders, and elongate bodies of members of the Brachylaimidae. In addition, they possess metraterms whose outer walls are lined with small gland cells and have larger gland cells free in the parenchyma surrounding the terminal genitalia and genital pore region, traits that are characteristic of members of the Brachylaimidae and Leucochloridiidae (Zamparo et al., 2003), the most species-rich families in the Brachylaimoidea. Finally, the phylogenetic analysis by Brooks et al. $(1985,1989)$ (see also Brooks and McLennan, 1993) suggested that a spinose cirrus is plesiomorphic for a group comprising the Brachylaimoidea (primarily the Leucochloridiidae + Brachylaimidae) + Strigeoidea (in which the Liolopidae is the sister group of the remaining families). The presence of a spinose cirrus, therefore, is not an indication that $B$. centrodes and the new species described herein should be excluded from the Brachylaimidae.

The 2 species in question also exhibit genital sacs containing both the cirrus and the pars prostatica, in contrast with the remaining brachylaimids, all of which exhibit genital sacs containing only the cirrus, both the pars prostatica and seminal vesicle lying free in the parenchyma (Cribb, 1992). Other members of the Brachylaimoidea exhibit the plesiomorphic condition, in which the genital sac contains a seminal vesicle, pars prostatica, and cirrus; hence, $B$. centrodes and the new species exhibit an intermediate morphology. Leucochloridiids and their putative closest relatives (see Pojmanska, 2002a, 2002b) also exhibit genitalia at the posterior end of the body, a presumptive synapomorphy for the group, in contrast with the genitalia occurring ventromedially in the mid-hind body, a trait exhibited by $B$. centrodes and the new species, which is the plesiomorphic condition for the entire order Strigeiformes (Brooks et al., 1985, 1989). Figure 3 is a cladogram summarizing the characters we have discussed above (as well as those previously reported by Brooks et al., 1985, 1989) in the context of the major taxa with which we have compared the 2 species inhabiting tinamus. These characters support the hypothesis that $B$. centrodes and the new species are diagnostically distinct and phylogenetically basal to all remaining brachylaimids. Consequently, we propose Tinamutrema for them; placing both species in Brachylaima would obscure information about the phylogenetic significance of the structure of their terminal genitalia. At the same time, we have not yet discovered a synapomorphy corroborating the monophyly of these two species, so we propose that Tinamutrema remain in the Brachylaimidae. The diagnosis for the Brachylaimidae should be emended to include species with a spinose and as pinose cirrus and species having the pars prostatica and cirrus contained within the genital sac, as well as those having only the cirrus contained within the genital sac.

\section{DISCUSSION}

As noted above, we do not at present have a synapomorphy for the 2 members of Tinamutrema, so the monophyly of the genus has not yet been corroborated. For that, we would need more detailed phylogenetic assessment of the members of the Brachylaimoidea. We would also expect the addition of molecular information to complement phylogenetic studies based on morphology, and we are attempting to obtain more specimens of $T$. canoae for such purposes.

\section{ACKNOWLEDGMENTS}

We are grateful to the scientific and technical staff of the ACG for supporting this study, in particular Elda Araya, Roger Blanco, Carolina Cano, Maria Marta Chavarría, Felipe Chavarría, Roberto Espinoza,
Dunia Garcia, Guillermo Jimenez, Elba Lopez, Sigifredo Marin, Alejandro Masis, Calixto Moraga, Fredy Quesada, and Petrona Rios. Thanks are also due to Dan Janzen and Winnie Hallwachs, scientific advisers to the ACG, for their support. Host specimens were collected by D.C., Jeremiah Trimble (MCZ), and Calixto Moraga (ACG) under the authority of CITES Permit US9258251, CITES Permit CR9123440, Costa Rica Ministero del Ambiente y Energia Licencia 203640283 and Resoluciones 215-2001-OFAU and 411-2001-OFAU, Harvard University IACUC Protocol 21-09, and USDA APHIS Permit 47956 (form VS16-6A). Host necropsy and parasite collections were made by D.R.B., D.C., Elda Araya, Sara Brant, Marie Causey, Ben Hanelt, Calixto Moraga, and Petrona Rios. This study was funded by a research grant from the Natural Sciences and Engineering Research Council of Canada to D.R.B. and by a grant from the MCZ Putnam Expedition Fund to D.C. Special thanks are due to Luis Muniz-Perreira of the Instituto Oswaldo Cruz for providing digital images and for loan of specimens of $B$. centrodes.

\section{LITERATURE CITED}

Alicata, J. 1940. The life cycle of Postharmostomum gallinum, the cecal fluke of poultry. Journal of Parasitology 26: 135-143.

Braun, M. 1901. Zur revision der Trematoden der Vogel. I. Centralblatt fur Bacteriologie 29: 560-568.

Brooks, D. R., S. M. BANdoni, C. A. Macdonald, AND R. T. O'Grady. 1989. Aspects of the phylogeny of the Trematoda Rudolphi, 1808 (Platyhelminthes: Cercomeria). Canadian Journal of Zoology 67: 2609-2624.

- AND D. A. MCLenNan. 1993. Parascript: Parasites and the language of evolution. Smithsonian Institution Press, Washington, D.C., 429 p.

, R. T. O'Grady, AND D. R. GLEN. 1985. Phylogenetic analysis of the Digenea (Platyhelminthes: Cercomeria) with comments on their adaptive radiation. Canadian Journal of Zoology 63: 411-443. -, AND R. M. OvERSTREET. 1978. The family Liolopidae (Digenea) including a new genus and two new species from crocodilians. International Journal for Parasitology 8: 267-273.

CRIBB, T. 1992. The Brachylaimidae (Trematoda: Digenea) of Australian native mammals and birds, including descriptions of Dasyurotrema n. g. and four new species of Brachylaima. Systematic Parasitology 22: $45-72$.

Dollfus, R. 1935. Sur quelques Brachylaemus de la Richelieu (Indre et Loire). Annales de Parasitologie 13: 52-79.

JENSEN, D. 1972. The life history of Scaphiostomum pancreaticum McIntosh, 1934 (Trematoda: Brachylaemidae). Canadian Journal of Zoology 50: 201-204.

JoYeuX, C., J.-G. BAER, AND J. TimON-DAvid. 1932. Le dévelopment du trématode Brachylaemus (Brachylaemus) nicolli (Wittenberg). Comptes Rendus de la Société de Biologie 109: 464-466.

KRULL, W. 1934. Some observations on the life history of Brachylaemus virginiana (Dickerson) Krull, W. 1934. Transactions of the American Microscopical Society 54: 118-134.

1935. Studies on the life history of Panopistus pricei Sinitsin, 1931 (Trematoda). Parasitology 27: 93-100.

PAVlov, P. 1946. Infestation expérimentale d'animaux domestiques par Brachylaemus. Annales de Parasitologie Humaine et Comparée 21: 94-95.

PoJMANSKA, T. 2002a. Superfamily Brachylaimoidea Joyeux \& Foley, 1930. In Keys to the Trematoda, D. I. Gibson, A. Jones, and R. A. Bray (eds.). CAB International and The Natural History Museum, London, U.K., p. 31-36.

2002b. Family Leucochloridiidae Poche, 1907. In Keys to the Trematoda, D. I. Gibson, A. Jones, and R. A. Bray (eds.). CAB International and The Natural History Museum, London, U.K., p. $47-51$.

Reynolds, B. 1938. Developmental stages of Panopistus pricei Sinitsin in Agriolimax agrestis. Parasitology 30: 320-323.

Timon-David, J. 1959. Recherches sur les kystes a Brachylaemus de 
cyclostome. Annales de Parasitologie 34: 271-287.

Ulmer, M. 1951a. Postharmonostomum helicis (Leidy, 1847) Robinson 1949, (Trematoda), its life history and a revision of the subfamily Brachylaeminae. Part I. Transactions of the American Microscopical Society 70: $189-238$.

. 1951b. Postharmonostomum helicis (Leidy, 1847) Robinson 1949, (Trematoda), its life history and a revision of the subfamily Brachylaeminae. Part I. Transactions of the American Microscopical Society 70: $319-347$.
YAMAGUTI, S. 1971. Synopsis of the digenetic trematodes of vertebrates. Keigaku Publishing Company, Tokyo, Japan, 1,074 p.

Zamparo, D., D. R. BROOKS, AND D. CAUSEY. 2003a. Whallwachsia illuminata n. g., n. sp. (Trematoda: Digenea: Plagiorchiformes: Prosthogonimidae) in the steely-vented hummingbird Amazilia saucerrottei (Aves: Apodiformes: Trochilidae) and the yellow-olive flycatcher Tolmomyias sulphurescens (Aves: Passeriformes: Tyrannidae) from the Area de Conservación Guanacaste, Guanacaste, Costa Rica. Journal of Parasitology 89; 814-818. 